\title{
Food Values, Spoilage Moulds and Aflatoxin Detection in 'Attiéké' (A Cassava Fermented Product)
}

\author{
Jonathan Segun G*, Bello Tunde S and Asemoloye Michael D \\ Department of Botany, Food and Environmental Mycology/Biotechnology Unit, University of Ibadan, Ibadan, Oyo State, Nigeria
}

\begin{abstract}
Derived foods from root and tuber crops, Attiéké for example, are often consumed by African populace. Attiéké is processed from Cassava (Manihot esculenta Crantz). Based on different methods adopted for its processing and storage, we present the food values, bio-deteriorating/spoilage fungi and aflatoxin contents of Attiéké samples, collected from different locations in Nigeria and Ivory Coast. Aflatoxin contents were detected using high Performance Liquid Chromatography (HPLC). Result obtained shows that the most frequent fungal contaminants in the samples are Aspergillus niger, Aspergillus flavus, Candida albicans, Mucor hiemalis and Penicillium chrysogenum. Records on the aflatoxin contents shows that the food samples contain AFB 1 (1.03-6.72 $\left.\mu \mathrm{g} \mathrm{kg}^{-1}\right), \mathrm{AFB}_{2}(2.46-2.56 \mu \mathrm{g} \mathrm{kg}-1)$ and $\mathrm{AFG}_{1}\left(1.43-9.57 \mu \mathrm{g} \mathrm{kg}^{-1}\right)$ range. It is also observed that the samples contain appreciable amount of Crude Protein $(0.48-0.73 \%)$ and Moisture Content $(45.89-49.96 \%)$ ranges with storage time, percentage Crude Fibre (CF) range from $1.08-1.12 \%, 0.14-0.18 \%$ Crude Fat (EE) and 0.45-0.49\% Percentage Ash.
\end{abstract}

Keywords: Attiéké; Food values; Moulds; Aflatoxins;Tolerance limit; Health threat

\section{Introduction}

Root and tuber crops are of immense importance to the feeding habit of African populace [1]. Cassava (Manihot esculenta Crantz) is consumed in various forms including Attiéké. Attiéké is becoming a daily intake for people in West and Central Africa that has a bed rock in it as an energy source [2]. It is a starchy-couscous dish derived from fermented Cassava dough processing and most importantly produced by Ivorian particularly the coastal population of the country [3]. Its appreciation is going beyond boundaries as a staple food due to black African-diaspora immigration [4]. In Cote d'Ivoire, Attiéké plays a large part in household sustenance with regards to its combat against hunger and also its nutritional supplements [5]. Attiéké is acknowledged to be representing 5\% food expenditure and 20.5\% Calories diet daily intake for consumers and its production is approximately estimated around 18965 to 40000 tons and consumption per inhabitants lies between 28 and $30 \mathrm{~kg}$ annually [5-8]. Its production still follows conventional procedure and not on modern procedure [9-11].

The preparation of attieke from cassava varies and numerous across different communities, though, the most complex aim is eliminating its bitterness and toxicity [12]. To avoid this, fermentation is carried out in numerous traditional transformation technologies of Cassava roots [13]. Its production proceed in the unit operations including peeling, grating, fermenting, pressing, crumbling, sieving, semolining, drying, air winding and cooking $[14,15]$. These units of operations proceeds traditionally, but unhygienic handling may lead to faster fungal deterioration and a resultant mycotoxicity.

Fungi which were ignorantly believed to be an anaesthetic organism growing on food had been lime lighted when the famous Turkey $\mathrm{X}$ diseases claimed lives of approximately 10,000 Turkish and lesser domestic birds in Great Britain [16]. This became informative that spoilage fungi could produce toxins named Aflatoxin: "A" obtained from Aspergillus and "fla" from flavus, where the name of the organism Aspergillus flavus was derived. Conditions that predispose food to these organisms include; hot and humid climate, damage by insects that decrease host's immunity, moisture content of $16 \%$ and above [17].

This research was embarked upon to investigate food values, spoilage moulds and aflatoxin detection in Attiéké from Nigeria and Ivory Coast.

\section{Materials and Methods}

\section{Collection of samples}

Samples of prepared ready for cooking 'Attiéké' (i.e., processed cassava dough) were randomly selected from two major table top food sellers in three (3) locations where 'Attiéké' has its best cook and very demanding consumers as shown below:

1. a) Ejigbo, Beulah Church (6 $\left.33^{\prime} 8^{\prime \prime} \mathrm{N}, 3^{\circ} 18^{\prime} 26^{\prime \prime} \mathrm{E}\right)$

b) Ejigbo (Ore meji), (6³0' $\left.8^{\prime \prime} \mathrm{N}, 3^{\circ} 18^{\prime} 20^{\prime \prime} \mathrm{E}\right)$

2. a) Iwo, BHS $\left(7^{\circ} 47^{\prime} 00 \mathrm{~N}, 4^{\circ} 12^{\prime} 00^{\prime \prime} \mathrm{E}\right)$

b) Iwo, Odo, ori market $\left(7^{\circ} 46^{\prime} 00 \mathrm{~N}, 4^{\circ} 12^{\prime} 00^{\prime \prime} \mathrm{E}\right)$

3. a) Adjame Bromokoute $1\left(5.36^{\circ} \mathrm{N}, 4.02^{\circ} \mathrm{W}\right)$

b) Adjame Bromokote $2\left(5.36^{\circ} \mathrm{N}, 4.02^{\circ} \mathrm{W}\right)$

These locations are tropics, according to climate data; they have an annual rainfall of $1247 \mathrm{~mm}, 1264 \mathrm{~mm}$ and $1781 \mathrm{~mm}$, respectively which last from April to October in Ejigbo and Iwo and from January to June in Adjame.

Variations due to different days of cooking were worked out such that they were all steamed at the same time. A total of six (6) samples were collected (2) samples from each location. The cooked samples

*Corresponding author: Jonathan Segun G, Department of Botany, Food and Environmental Mycology/Biotechnology Unit, University of Ibadan, Ibadan, Oyo State, Nigeria, Tel: +2348164746758; E-mail: asemoloyemike@gmail.com

Received September 10, 2017; Accepted October 25, 2017; Published October 31, 2017

Citation: Jonathan Segun G, Bello Tunde S and Asemoloye Michael D (2017) Food Values, Spoilage Moulds and Aflatoxin Detection in 'Attiéké' (A Cassava Fermented Product). J Microb Biochem Technol 9:244-248. doi: 10.4172/1948-5948.1000372

Copyright: (c) 2017 Jonathan Segun G, et al. This is an open-access article distributed under the terms of the Creative Commons Attribution License, which permits unrestricted use, distribution, and reproduction in any medium, provided the original author and source are credited. 
were placed in clean sterile polythene bags, securely tied, labeled and transported to the laboratory.

\section{Research treatments and design}

Appreciable gram of each sample was taken and divided into three (3); one-third was stored in the freezer at subzero degree for aflatoxin analysis, the second fraction was stored at room temperature for nutrient analysis and the other was used immediately for isolation of fungi. The experiment was laid in Completely Randomized Design with three replicates.

\section{Isolation and characterization of fungi biota}

The isolation of fungi was carried out according to procedure described by Jimoh and Kolapo [18]. All samples collected were conditioned in a sterile package. About $2 \mathrm{~g}$ of each of the samples taken at random were aseptically placed in three replicates of Petridishes containing Potato Dextrose Agar and Lactic acid $\left(10.53 \mathrm{gL}^{-1}\right)$. The dishes were incubated at $27 \pm 2^{\circ} \mathrm{C}$ for 3-6 days. Fungal cultures obtained were subsequently sub-cultured for purification. Upon fungi maturation, they were characterized based on cultural and morphological features such as colony diameter, colony color on agar, front and reverse and colony texture. Slide culture was then prepared and incubation in moist chambers at $26 \pm 2^{\circ} \mathrm{C}$ for 4 days before observation under a light microscope (labomed, model $\mathrm{CxL}$ ). Mycological keys and manuals were used for macro and microscopic features that are commonly used identification of fungi, which were conidiophores, conidial shape, phialides and metulae, presence and shape of vesicles [19].

\section{Aflatoxin detection}

The modified method of using HPLC chromatography was followed in determining aflatoxin concentrations of Aflatoxin B1 $\left(\mathrm{AFB}_{1}\right)$, Aflatoxin $\mathrm{B} 2\left(\mathrm{AFB}_{2}\right)$ and Aflatoxin $\mathrm{G} 1\left(\mathrm{AFG}_{1}\right)$ [20]. The samples were injected into the HPLC column heated to $40^{\circ} \mathrm{C}$ using mainly reversedphased columns, with mobile phases composed of water: methanol solution $(60: 40, \mathrm{v} / \mathrm{v})$. To $1 \mathrm{~L}$ of mobile phase were added $119 \mathrm{mg}$ of Potassium bromide and $350 \mathrm{Bl}$ of $4 \mathrm{M}$ nitric acid (required for post/ column electrochemical derivatisation with Kobra Cell, ROBiopharm Rhone). This method is used after an extraction with acetonitrile and water, reaching limits of qualification between 0.012 and $0.073 \mu \mathrm{g} \mathrm{kg}^{-1}$ was used. The coupling of HPLC to mass spectrometry was also used for the detection technique at the excitation wavelength of $362 \mathrm{~nm}$ and the emission wavelength was $425 \mathrm{~nm}$. The ionization sources employed was based on atmospheric pressure [21,22]. The sample was calculated by analyzing triplicates of six samples. The method showed recoveries between $95 \%$ and $114 \%$ with a LOQ of $1.5 \mathrm{ngmL}^{-1}$.

\section{Crude protein determination}

The crude protein in the samples was determined by the routine semi-micro Kjeldahl, procedure. $0.5 \mathrm{~g}$ of each finely ground dried sample was weighed carefully into the Kjeldahl digestion tubes, 1 tablet of selenium catalyst and $10 \mathrm{ml}$ of conc. $\mathrm{H}_{2} \mathrm{SO}_{4}$ was added into the digestion preset at $500^{\circ} \mathrm{C}$. The digestion was left for $4 \mathrm{~h}$ in a fume cupboard. The tube was placed in a distilling unit and $5 \mathrm{ml}$ of $40 \%$ $\mathrm{NaOH}$ was added to it. The mixture was steam distilled for 2 min into a $50 \mathrm{ml}$ flask containing $10 \mathrm{ml}$ of $2 \%$ Boric acid, mixed with indicator solution which was then titrated against $0.01 \mathrm{~N} \mathrm{HCl}$ until a wine color was obtained. The quantification was done using AOAC procedure [23].

\section{Crude fat determination}

$1 \mathrm{~g}$ of each dried sample was weighed into fat free extraction thimble and plug lightly with cotton wool. A soxhlet flask was then filled to $3 / 4$ of its volume with petroleum ether and the ether was left on heater to siphon until it was short of siphoning. Ether content of the extractor was drained into the ether stock bottle. The thimble containing sample was then removed and dried on a clock glass on the bench top. The extractor, flask and condenser were replaced and the distillation continued until the flask was practically dry. The flask containing the fat was detached; its exterior cleared and dried to a constant weight in the oven, and the crude fat was determined [23].

\section{Dry matter and moisture determination}

$2 \mathrm{~g}$ of the sample were weighed into a previously weighed crucible (Wo). The crucible plus sample $\left(\mathrm{W}_{1}\right)$ taken was then transferred into the oven set at $100^{\circ} \mathrm{C}$ to dry to a constant weight for $2 \mathrm{~h}$. At the end, the crucible plus sample was removed from the oven and transferred to desiccators, cooled for ten minutes and weighed $\left(\mathrm{W}_{3}\right)$ [23].

$$
\begin{aligned}
& \text { \% Dry Matter }(\mathrm{DM})=\frac{\mathrm{W}_{3}-\mathrm{Wo}_{\mathrm{O}}}{\mathrm{W}_{1}-\mathrm{Wo}_{\mathrm{O}}} \times 100 \\
& \% \text { Moisture }=100-\% \mathrm{DM} \text {. }
\end{aligned}
$$

\section{Ash determination}

$2 \mathrm{~g}$ of the sample was weighed into a porcelain crucible. This was transferred into the muffle furnace set at $550^{\circ} \mathrm{C}$ and left for about 4 h. About this time it had turned to white ash. The crucible and its content were cooled to about $100^{\circ} \mathrm{C}$ in air, then room temperature in a desiccator and weighed [23].

$$
\text { Ash content }=\frac{\text { weight of ash }}{\text { Original weight of sample }} \times 100
$$

\section{Fibre determination}

$2 \mathrm{~g}$ of the sample was weighed accurately into the fibre flask and 100 $\mathrm{ml}$ of $0.255 \mathrm{~N} \mathrm{H}_{2} \mathrm{SO}_{4}$ was added. The mixture was heated under reflux for $1 \mathrm{~h}$ with the heating mantle. The hot mixture was filtered through a fibre sieve cloth. The residue was returned to the fibre flask to which 100 $\mathrm{ml}$ of $(0.313 \mathrm{~N} \mathrm{NaOH})$ was added and heated under reflux for another $1 \mathrm{~h}$. The mixture was filtered through a fibre sieve cloth and $10 \mathrm{ml}$ of acetone added. The residue was washed with about $50 \mathrm{ml}$ hot water on the sieve cloth before it was finally transferred into the crucible. The crucible and the residue were oven-dried at $105^{\circ} \mathrm{C}$ overnight to drive off moisture. The oven-dried crucible containing the residue was cooled in a desiccator and weighed to obtain the weight $\mathrm{W}_{1}$. The crucible with weight $\mathrm{W}_{1}$ was transferred to the muffle furnace for ashing at $550^{\circ} \mathrm{C}$ for $4 \mathrm{~h}$. The crucible containing white or grey ash was cooled in the desiccator and weight to obtain $\mathrm{W}_{2}$. The difference $\mathrm{W}_{1}-\mathrm{W}_{2}$ gives the weight of fibre [23].

$$
\% \text { Fibre }=\frac{\mathrm{W}_{1}-\mathrm{W}_{2}}{\text { Weight of sample }} \times 100
$$

\section{Statistical Analysis}

Data were subjected to Statistical Analysis of Variance (ANOVA) at $95 \%$ and $99 \%$ probability levels using SAS 9.3 statistical package and means were separated using Duncan Multiple Range Test.

\section{Results}

The result in Table 1 shows the Mean Nutritional composition in wet Attiéké samples collected from different location under different storage periods. The samples were highly significant $(\mathrm{P}<0.01)$ for crude protein and moisture contents, but significant $(\mathrm{P}<0.05)$ for Crude fibre, Crude Fat and ash contents. It was observed that that all the samples were significantly different from each other for crude protein. The 
Citation: Jonathan Segun G, Bello Tunde S and Asemoloye Michael D (2017) Food Values, Spoilage Moulds and Aflatoxin Detection in 'Attiéké' (A Cassava Fermented Product). J Microb Biochem Technol 9:244-248. doi: 10.4172/1948-5948.1000372

crude protein obtained from samples from Ivory Coast stored for three days was significantly higher $(\mathrm{P}<0.05)$ than other samples while the least mean value was obtained from sample collected from Nigeria with storage period of a day (Table 1).

The result also shows that the Crude fibre of sample collected from Ivory Coast stored for one day is significantly higher but not different from Ivory Coast samples stored for two days. Also, sample collected from Nigeria stored for one day and three days were non significantly different from each other, but different from sample collected from Nigeria stored for two days and sample collected from Ivory Coast stored for three days were not significantly different from each other.

The Crude Fat of samples from Nigeria stored for three days were

\begin{tabular}{|l|c|c|c|c|c|}
\hline Samples & $\begin{array}{c}\text { Crude Protein } \\
\text { (\%) }\end{array}$ & $\begin{array}{c}\text { Crude Fibre } \\
\mathbf{( \% )}\end{array}$ & $\begin{array}{c}\text { Crude Fat } \\
\mathbf{( \% )}\end{array}$ & Ash (\%) & $\begin{array}{c}\text { Moisture } \\
\text { Content (\%) }\end{array}$ \\
\hline A18 & $0.48 f$ & $1.10 a b$ & $0.18 a$ & $0.46 b c$ & $45.89 \mathrm{e}$ \\
\hline B18 & $0.56 \mathrm{e}$ & $1.12 \mathrm{a}$ & $0.17 \mathrm{ab}$ & $0.48 \mathrm{ab}$ & $49.90 \mathrm{~b}$ \\
\hline A19 & $0.61 \mathrm{~d}$ & $1.08 \mathrm{~b}$ & $0.15 \mathrm{bc}$ & $0.45 \mathrm{c}$ & $43.83 \mathrm{f}$ \\
\hline A20 & $0.69 \mathrm{c}$ & $1.10 \mathrm{ab}$ & $0.14 \mathrm{c}$ & $0.47 \mathrm{abc}$ & $46.49 \mathrm{~d}$ \\
\hline B19 & $0.71 \mathrm{~b}$ & $1.11 \mathrm{a}$ & $0.15 \mathrm{bc}$ & $0.49 \mathrm{a}$ & $49.32 \mathrm{c}$ \\
\hline B20 & $0.73 \mathrm{a}$ & $1.08 \mathrm{~b}$ & $0.14 \mathrm{c}$ & $0.49 \mathrm{a}$ & $49.96 \mathrm{a}$ \\
\hline
\end{tabular}

Mean with the same letter in a column are not significantly different from each other at $p>0.05$

Table 1: Nutritional composition of wet attiéké sample. not significantly $(\mathrm{P}>0.05)$ different from Ivory Coast samples stored for three days. The highest mean value of Wet Attiéké Crude Fat was recorded from Nigeria stored for one day. The ash content of samples collected from Ivory Coast stored for two days and three days were not significantly different from each other while the least ash content of Wet Attiéké was obtained from Nigeria sample stored for two days.

Highest moisture content was observed from samples collected in Ivory Coast stored for three days while the least moisture content of Attiéké was obtained from Nigeria sample stored for two days.

Nigeria stored for one day; A18, Nigeria stored for two days; A19, Nigeria stored for three days; A20, Ivory Coast stored for one day; B18, Ivory Coast stored for two day; B19, Ivory Coast stored for three day;B20.

Results obtained in this study showed that the spoilage fungi found associated with Attiéké include; Penicillium chrysogenum, Aspergillus niger, Candida albicans, Aspergillus flavus and Mucor hiemalis as shown in Figures 1a-1f.

It was also observed in Table 2 that, Attiéké samples collected from Adjame Bromokoute 1 and Adjame Bromokoute 2 had the highest number of fungi occurrence followed by Iwo Odoori, Iwo BHS, Ejigbo Ore meji collection with Ejigbo Beulah having the least growth However studying these samples, the rate of occurrence of aflatoxigenic
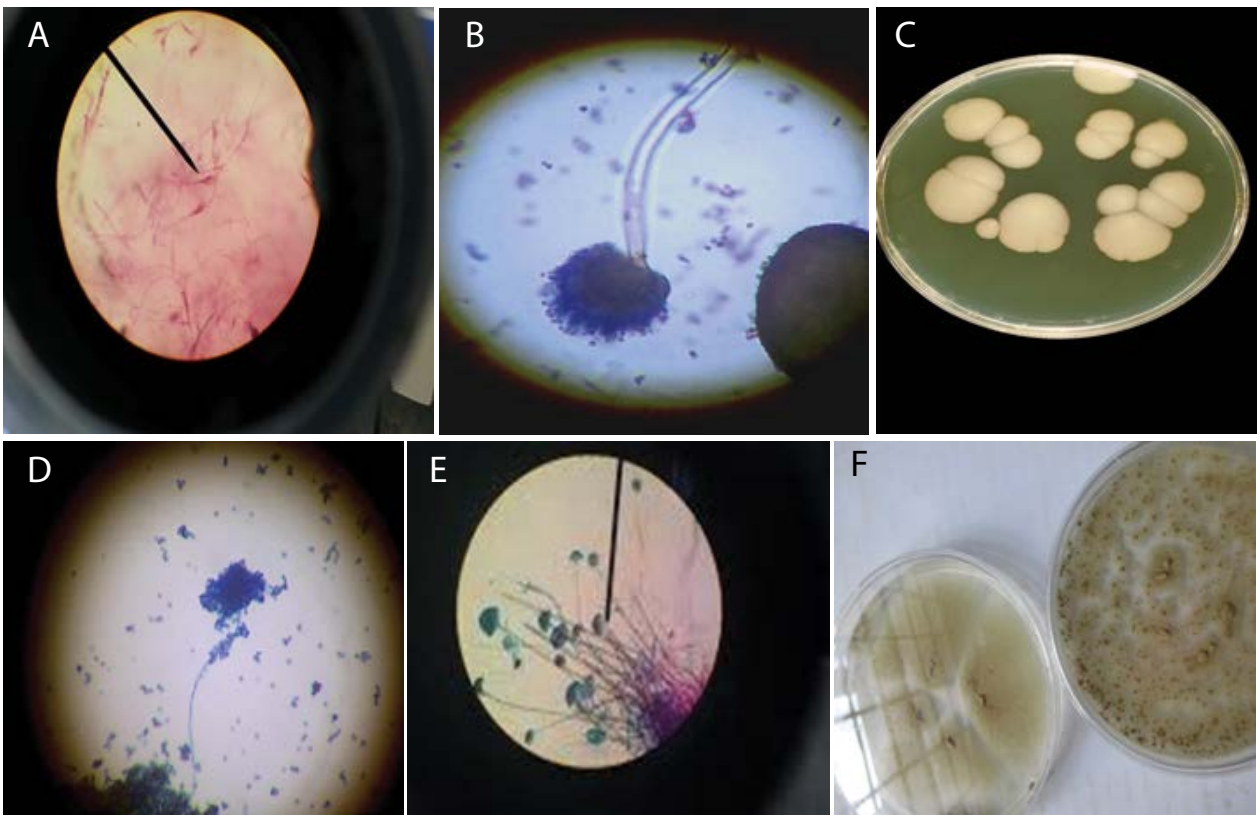

Figure 1: Bio-deteriorating fungal contents in 'Attieke' samples. a: Photomicrograph of Penicillium chrysogenum. b: Photomicrograph of Aspergillus niger. c: Pure culture of Candida albicans in PDA media plate. d: Photomicrograph of Aspergillus flavus. e: Photomicrograph of Mucor hiemalis. f: Pure culture of Mucor hiemalis in PDA media plate.

\begin{tabular}{|l|c|c|c|c|c|}
\hline Fungal isolates & Ejigbo Ore meji & Adjame Bromokote 1 & Iwo Odoori & Adjame Bromokote 2 & Iwo BHS \\
\hline Penicillium chrysogenum & - & - & - & + & - \\
\hline Aspergillus niger & + & + & + & + & + \\
\hline Candida albicans & + & + & + & + & + \\
\hline Aspergillus flavus & + & + & + & + & + \\
\hline Mucor hiemalis & - & + & - & - & - \\
\hline
\end{tabular}

+ Presence of fungi; - Absence of fungi

Table 2: Occurrences of 'attieke' biodeteriorating fungi in different locations. 


\begin{tabular}{|l|c|c|c|}
\hline Sample & AFB $_{\mathbf{1}}(\boldsymbol{\mu} \mathbf{g} / \mathbf{k g})$ & $\mathbf{A F B}_{\mathbf{2}}(\boldsymbol{\mu g} \mathbf{g} \mathbf{k g})$ & $\mathbf{A F G}_{\mathbf{1}}(\boldsymbol{\mu} \mathbf{g} / \mathbf{k g})$ \\
\hline Adjame Bromokoute 1 & $1.64 \mathrm{c}$ & $2.53 \mathrm{~b}$ & $1.51 \mathrm{c}$ \\
\hline Ejigbo Ore meji & $5.03 \mathrm{~b}$ & $2.46 \mathrm{~d}$ & $2.88 \mathrm{a}$ \\
\hline Ejigbo Beulah & $6.08 \mathrm{a}$ & $2.48 \mathrm{c}$ & $9.57 \mathrm{f}$ \\
\hline Iwo BHS & $6.12 \mathrm{a}$ & $2.56 \mathrm{a}$ & $1.44 \mathrm{~d}$ \\
\hline Adjame Bromokoute 2 & $6.47 \mathrm{a}$ & $2.48 \mathrm{c}$ & $1.43 \mathrm{e}$ \\
\hline Iwo Odoori & $6.72 \mathrm{a}$ & $2.54 \mathrm{~b}$ & $1.95 \mathrm{~b}$ \\
\hline
\end{tabular}

Mean with the same letter in a column are not significantly different from each other at $\mathrm{P}>0.05$

Table 3: Aflatoxin concentrations in different 'Attiéké' samples.

\begin{tabular}{|l|c|c|c|c|c|c|}
\hline Proximate Analysis & $\begin{array}{c}\text { Crude } \\
\text { Fibre }\end{array}$ & $\begin{array}{c}\text { rude } \\
\text { Fat }\end{array}$ & Ash & $\begin{array}{c}\text { Moisture } \\
\text { Content }\end{array}$ & Replicate & Sample \\
\hline Crude Protein & -0.20 & $-0.80^{* *}$ & $0.51^{*}$ & 0.38 & 0.01 & $0.95^{* *}$ \\
\hline Crude Fibre & & 0.40 & 0.36 & 0.45 & 0.20 & -0.32 \\
\hline Crude Fat & & & -0.22 & -0.08 & 0.12 & $-0.80^{* *}$ \\
\hline Ash & & & & $0.84^{* *}$ & 0.08 & 0.46 \\
\hline Moisture Content & & & & & 0.00 & 0.33 \\
\hline Replicate & & & & & & 0.00 \\
\hline
\end{tabular}

${ }^{*} \mathrm{P}<0.05=$ significant, ${ }^{* *} \mathrm{p}<0.01=$ highly significant

Table 4: Correlation matrix of the nutritional composition of wet attiéké sample.

fungi (Aspergillus sp.) was higher in the order; Iwo Odoori>Iwo BHS $>$ Adjame Bromokoute 2>Adjame Bromokoute $1>$ Ejigbo Ore meji>Ejigbo Beulah. In a contrasting situation, the occurrence of nonaflatoxic fungus was observed in the samples (Table 2).

The result shown in Table 3 shows the mean Aflatoxin concentrations of $\mathrm{AFB}_{1}, \mathrm{AFB}_{2}$ and $\mathrm{AFG}_{1}$ in the studied Attiéké samples which are significantly different across each location $(\mathrm{P}<0.01)$, but $A F B_{1}$ found in samples from Ejigbo Beulah, Iwo BHS, Adjame Bromokoute 1 and Iwo Odo ori were not significantly different from one another, while the least $\mathrm{AFB}_{1}$ was observed in sample from Adjame Bromokoute 2 (Table 3).

There were also no significant differences between the $\mathrm{AFB}_{2}$ found in sample from Adjame Bromokoute 1 and Iwo Odoori but significantly different from sample from Ejigbo Beulah and Adjame Bromokoute 2 which are not significantly different from each other. The least $\mathrm{AFB}_{2}$ concentration of Attiéké was obtained from sample collected from Adjame Bromokoute2. However, there were differences in all the $A F G_{1}$ concentration in the sample, the highest $A F G_{1}$ was obtained from sample Ejigbo Beulah, while the least $\mathrm{AFG}_{1}$ was found in sample Adjame Bromokoute 2.

Results (Table 4) also show the correlation between all the proximate compositions in wet Attiéké. The crude protein is negative and strongly correlated with the crude fat $(\mathrm{r}=-0.80)$ and positively associated $(\mathrm{r}=0.50)$ with the ash content. There was negative and some correlation between the sample and Crude Fat $(\mathrm{r}=-0.80)$ while the sample is positive and strongly correlated with Crude Protein. Crude Fat shows a negative correlation and highly correlated with the sample while the ash content is positive and strongly correlated ( $r=0.84)$ with the moisture content of the sample.

\section{Discussion}

Results obtained on proximate compositions of food correlates with previous observations on 'Attiéké' [24]. A slight progression in moisture was recorded as the storage period increases as similarly reported, they opined that cassava dough and yam chips absorbed moisture during storage, and enhances the growth of fungi and other spoilage organisms
$[25,26,27]$. The effect of moisture absorbed increases the water activity as a result of degrading activity of these fungi.

Furthermore, percentage crude fat, crude fibre observed decreased with storage period. This might be as a result of microbial degradation of nutritive substances in this food by certain fungi that coursed for their growth and development.

Lack of growth not until the third day could be the reductive effect of steam (heat) on the vegetative microorganisms as similarly reported, and not until then that emergence of spores that growth was recorded [28].

The variation in occurrence of fungi biomass across the samples could be as a result of different methods of handling which include processing and storage. Penicillium chrysogenum had been reported to be associated with damp or wet material which could be an indication of unhygienic water source [29]. Mucor hiemalis and Candida albicans observed in this study were also reported to be found from Cassava products such as; Attiéké, Fufu and Lafun. A. flavus and A. niger also characterized in this study were reported to be aflatoxigenic fungi found in Garri Aadun and in suya spices [30-34].

The aflatoxin concentrations across different locations were so high, though some authors reported a much higher level in dried cassava chips [35]. This could be due to deteriorated tubers predisposed to aflatoxin producing fungi which was similarly confirmed [36]. Also, the storage method of Cassava dough through refrigeration, left for days before final steaming (though the flavour, taste and color used to adjudge its quality were still pristine) also makes the food susceptible to fungal contamination and aflatoxin production. Studies in these locations further revealed that most of the production process involved in the making of Attiéké follows the usual traditional technologies. Sack container used in packing and pressing could be a reservoir of different fungal growth. The drying of Cassava dough on ground surfaces predisposes these to contamination from dust, fungi and other lamentable materials. Some reported that such practice enhanced association between the products and the soil which is the primary habitat of fungi [37]. Maize cobs were reported to have a much higher aflatoxin level when dried on ground though, this is worse in peeled cassava because the inherent protection in tuber will have been removed by peeling. Inherent protection in grain husks had been reported to safeguard rice and maize from aflatoxin contamination, fungi and weevils infestation [38-41].

\section{Conclusion}

The results of this study showed that major spoilage (biodeteriorating) fungi of Attiéké from Ejigbo, Iwo and Adjame in West Africa were mostly molds with Aspergillus niger and A. flavus having highest occurrence and Candida albicans and their percentage occurrence has direct effect on its food values. Obviously this food is distributed to other villages, towns, cities and countries notably Ife-Odan, Osogbo, Sekondi-Takoradi, this is an indication that if not properly managed consumers of this delicacy will be at risk of aflatoxicosis. Thus, modern technologies for hygienic storage mechanisms and proper sanitary measures are needed to be put in place. Adequate information concerning the level of fungi and aflatoxin contamination of this food and how to reduce the risks of exposure to aflatoxin during its processing and storage are needed to be conveyed to all level of society. 
Citation: Jonathan Segun G, Bello Tunde S and Asemoloye Michael D (2017) Food Values, Spoilage Moulds and Aflatoxin Detection in 'Attiéké' (A Cassava Fermented Product). J Microb Biochem Technol 9:244-248. doi: 10.4172/1948-5948.1000372

\section{References}

1. Terry ER, Doku EU, Arene OB, Mahungu NM (1983) Plantes racines tropicales: Culture et emplois en afrique.

2. Kohou F, Michel P (1988) Céréales en regions chaudes: Conservation et transformation. John libbey eurotext paris.

3. Kouadio NA, Angbo SF, Mosso K (1991) Etude Comparative, Méthodes de Préparations Traditionnelles de l'attiéké dans le sud de la Côte d'Ivoire. Industries Alimentaires et Agricoles 108: 703-706.

4. Kouassi B, Traoré A, Sirpé G (2008) Transformation et consommation des denrées alimentaires en Afrique de l'Ouest Centrale. Edition Katharina ISBN: 97828458697: 141-145.

5. Bendech A, Chauliac M, Rerolle GP, Kante N, Malvy DJ (2000) Les Enjeux du consommateur en milieu urbain a Bamako. Journal de Sante Publique 12 $45-63$.

6. Giraud E, Brauman A, Kelele S, Gosselin L, Raimbault M (1995) Contrôle de la fermentation du manioc pour un meilleur gari: Utilisation d'un ferment de Lactobacillus plantarum à activité linamarase et amylase in Transformation alimentaire du manioc. Edition Orstorm Paris ISBN 2-7099-1279-1: 224-233.

7. Trèche $S$ (1995) Importance du manioc en alimentation humaine dans différentes régions du monde. In: Transformation alimentaire du manioc. Edition Orstorm Paris 234-243.

8. FAO (2001) Production et exportation annuelles de manioc: Marche tropicaux. Food and Agricultural Oganisation Rome Italy 55: 170.

9. Essers S, Bosveld M, Van Der Grift RM (1993) Studies on the quantification of specific cyanogens in cassava products and introduction of a new chromogen J Science Food Agri 63: 287-296.

10. Fortin J, Desmarais G, Assovie O, Diallo M (1998) L'Attiéké couscous de la Côte d'Ivoire. Le monde Alimentaire, pp: 2-6.

11. Mosso K, Aboua F, Gnakri D (2000) Détoxication en cyanure des aliments dérivés du manioc. Industrie Alimentaire et Agricole 117: 41-42.

12. Sahore DA, Nemlin GJ (2012) Changes in biochemical properties of fresh attiéké during its storage. Food Public Health 2: 99-103.

13. Djeni NT, N'Guessan KT, Dadier AT, Djè KM (2008) Impact of different levels of a traditional starter on the fermentation of cassava. Food Global Science Books 2: 10-13.

14. Aboua $F$ (1998) Optimum conditions for cooking attiéké centre ivoirien de recherche technologique. J Trop Sci 38: 220-223.

15. Sotomey M, Ategbo EAD, Mitchipkpe EC, Gutierrez ML, Nago MC (2001) Innovation et diffusion des produits alimentaires en Afrique: l'attiéké au Bénin Savoir-faire et innovation en agroalimentaire en Afrique de l'Ouest. CIRAD 1-97.

16. Sargeant K, O'Kelly J, Carnaghan RBA, Allcroft R (1991) The assay of a toxic principle in certain groundnut meals. Vet Rec 73: 1219-1222.

17. Hamblin AM (2000) A focus on aflatoxin Smoked dried fishes samples stored for sale in contamination complication. Publication papers, p: 4

18. Jimoh KO, Kolapo AL (2008) Mycoflora and aflatoxin production in marke samples of some selected Nigerian food stuffs. Res J Microbiol 3: 169-174

19. Malgorzata R, Loannou M (2012) Teaching Resources From Microbiology Laboratory. Hals Oer Project De Montfort University.

20. Huang B, Ham Z, Wub $Y$, Ren $Y$ (2010) Simultaneous determination of aflatoxins $B_{1}, B_{2}, G_{1}, M_{1}$ and $M_{2}$ in peanut and their derivate product by ultrahigh-performance liquid chromatography-tandem mass spectrometry. Anal Chim Acta 662: 62-68.

21. Cavaliere C, Foglia P, Guarino C, Nazzari M, Samperi R, et al. (2007)
Determination of aflatoxins in olive oil by liquid chromatography-tandem mass spectrometry. Anal Chim Acta 596: 141-148.

22. Beltran E, Ibanez M, Sancho J, Cortes M, Yusa V, Hernandez F (2011) UHPLCMMS/MS highly sensitive determination of aflatoxion metabolite M1 and ochratoxion in a baby food and milk. Food Chem 126: 737-744.

23. AOAC (2005) Official methods of analysis of AOAC International $18^{\text {th }}$ Eds association of official analytical chemists. Arlington Virginia USA 65: 1199-1221.

24. Aboua $F$ (1989) Simple methods for evaluating attiéké spoilage in food chemistry. Trop Sci CIRT Abidjan 31: 313-317.

25. Jonathan SG, Ajayi L, Omitade $Y$ (2011) Nutritional compositions, fungi and aflatoxins detection in stored 'gbodo' fermented (Dioscorea rotundata) and 'elubo ogede' fermented (Musa paradisiaca) from south western Nigeria. Afr J Food Sci 5: 105-110.

26. Gbolagade JS (2005) Bacteria associated with cultures of Psathyrella atrombonata (pegler) and Schizophyllum commune (fr.ex.fr) Nigerian edible mushrooms. Acta Phytopathologica Et Entomologica Hungarica 40: 333-340.

27. Jonathan SG, Adeniyi MA, Asemoloye MD (2016a) Nutrient value, funga biodeterioration and aflatoxin contamination of suya spices a novel Nigerian indigenous snack. Hindawi - Scientifica 2016: ID 4602036

28. Coulin P, Farah Z, Assanvo JB, Spillmann J, Puhan Z (2006) Characterization of the microflora of the fermented cassava product attiéké during traditional small scale preparation. Int J Food Microbiol 2: 131-136.

29. Samson RA, Honbraken J, Thrane U, Frisvad JC, Anderson B (2010) Food and indoor Fungi. CBS Laboratory Manual Series utrecht Netherlands, p: 390.

30. Kouamé AK, Djeni TN, N'Guessan FK, Dje MK (2012) Post-processing microflora of commercial Attiéké produced in the south of Côte d'Ivoire. Society for Appl Microb 56: 44-50.

31. Omafuvbe BO, Adigun AR, Ogunsuyi JL, Asunmo AM (2007) Microbial diversity in ready-to-eat fufu and lafun-fermented cassava products sold in lle-lfe Nigeria. Res J Microb 2: 831.

32. Jonathan SG, Abdul-Lateef MB, Ayansina ADV (2013) Fungal and aflatoxin detection in fresh and stored 'garri ijebu' (locally processed food) Manihot esculenta. Report and Opinion 5: 13-19.

33. Jonathan SG, Adeniyi MA, Asemoloye MD (2015) Fungal biodeterioration aflatoxin contamination and nutrient value of 'aadun'. Researcher 7: 26-32.

34. Jonathan SG, Asemoloye MD, Abe A, Olawuyi OJ, Aina D (2016b) Food value, fungi and aflatoxin detection in stored 'orunla' Abelmoschus esculentus L. (Moench) from Ibadan. Nigeria. Researcher 8: 7-18.

35. Kaaya NA, Warren HL (2005) A review of past and present research on aflatoxin in Uganda. Afr J Food Agric Nutr Dev 5:1.

36. Mestres C, Bassa S, Fagbohoun E, Nago M, Hell K (2004) Yam chip food subsector: Harzadous practices and presence of aflatoxins in Benin. J Stored Prod Res 40: 575-585.

37. Diener UL, Cole RJ, Sanders TH, Payne AG, Lee LS, et al. (1987) Epidemiology of aflatoxin foundation by Aspergillus flavus. Ann Rev Phytopathol 5: 249-270.

38. Hell K, Cardwell KF, Poehling HM (2003) Relationship between management practices, fungal infection and aflatoxin for stored maize in Benin. J Phytopathol 151: $690-698$

39. Kaaya AN, Kyamuhangire W, Kyamanywa S (2006) Factors affecting aflatoxin contamination of harvested maize in the three agro-ecological zones in Uganda. J Applied Sci 6: 2401-2407.

40. Udoh JM, Cardwell KF, Ikotun T (2000) Storage structures and aflatoxins content of maize in five agro-ecological zones of Nigeria. J Stored Prod Res 36: 187-201.

41. Liu Z, Gao J, Yu J (2006) Aflatoxins in stored maize and rice grains in Liaoning province China. J Stored Prod Res 42: 468-479. 